\title{
Presupozycje a wzmocnienie
}

\section{Presuppositions and reinforceability}

\begin{abstract}
This paper describes the experiment concerning reinforceability of conversational implicatures and presuppositions. In the field of pragmatics it is assumed that conversational implicatures can be reinforced while presuppositions cannot. Test subjects evaluated a set of statements containing implicatures and presuppositions which were presented in two versions: non-reinforced and reinforced. Results of the experiment suggest that not only implicatures but also statements that contain implicative verbs can be reinforced without sense of anomalous redundancy.
\end{abstract}

Keywords: pragmatics, presuppositions, implicative verbs, reinforceability, conversational implicature

W niniejszym artykule opisywane jest badanie wzmacnialności implikatur konwersacyjnych oraz presupozycji. W rozważaniach teoretycznych z zakresu pragmatyki przyjmuje się, że implikatury konwersacyjne mogą podlegać wzmocnieniu, natomiast presupozycje nie. Badani oceniali pod względem wywoływania poczucia językowej redundancji zbiór wypowiedzi zawierających implikatury konwersacyjne oraz presupozycje w wersji normalnej i wzmocnionej. Wyniki badań zdają się potwierdzać, że implikatury konwersacyjne podlegają wzmocnieniu bez wywoływania poczucia nieprawidłowej redundancji, zaś presupozycje są zróżnicowane pod kątem wywoływania poczucia nieprawidłowej redundancji ze względu na rodzaj konstrukcji wprowadzającej presupozycje.

Celem tego artykułu jest przedstawienie raportu $\mathrm{z}$ badania $\mathrm{z}$ obszaru pragmatyki eksperymentalnej dotyczącego wzmacnialności implikatur konwersacyjnych oraz presupozycji. Rozważania teoretyczne z dziedziny pragmatyki wskazują na to, że implikatury mogą podlegać wzmocnieniom, czyli że można jawnie zawrzeć treść implikowaną w wypowiedzi, nie wzbudzając poczucia nieprawidłowej redundancji. Odnośnie do presupozycji natomiast przewiduje się, że takie wzmocnienie będzie wywoływało poczucie nieprawidłowej redundancji. W niniejszej pracy będziemy starali się przetestować owe teoretyczne założenia. Główną motywacją do podjęcia badań była obserwacja, że konsekwencje różnych teorii pragmatycznych często nie są dostatecznie dobrze przetestowane eksperymentalnie. Intuicje użytkowników języka mogą pomóc nam w rozstrzygnięciu pewnych spornych kwestii na gruncie prag- 
matyki lub doprowadzić do lepszego zrozumienia pewnych zjawisk. Wyniki takich badań mogą również mieć nieocenione konsekwencje dla kognitywistycznych modeli kompetencji komunikacyjnej. W artykule opiszemy najpierw zjawiska pragmatyczne, jakimi są implikatury konwersacyjne oraz presupozycje. Następnie przejdziemy do opisania problemu wzmacnialności i zdefiniowania nieprawidłowej redundancji. W ostatniej części artykułu zaprezentujemy schemat i przebieg badania oraz wyniki i ich omówienie.

\section{Implikatury konwersacyjne}

Implikatury konwersacyjne są jednym z najbardziej znanych zjawisk pragmatycznych. Pojęcie to wprowadził Paul Grice [1975], on też poddał to zjawisko systematycznemu badaniu. Z implikaturą konwersacyjną mamy do czynienia w sytuacjach, w których to, co nadawca wypowiedział, różni się od tego, co nadawca miał na myśli. Przykładem implikatury konwersacyjnej może być poniższa wymiana zdań pomiędzy osobą A i osobą B:

\section{[1] A: Czy idziemy dzisiaj do kina?}

B: Niestety bardzo boli mnie głowa.

Zauważmy, że na poziomie znaczenia konwencjonalnego zdanie wypowiedziane przez osobę B nie wydaje się odpowiedzią na pytanie postawione przez osobę A. Jeżeli jednak osoba A jest kompetentnym użytkownikiem języka, możemy założyć, że nie będzie miała problemu z odczytaniem tego, co osoba B implikowała: że nie ma ochoty dzisiaj udać się do kina. Analiza zjawiska implikatur konwersacyjnych doprowadziła Grice’a do wyróżnienia dwóch poziomów znaczenia mówiącego: to, co powiedziane (what is said), oraz to, co mówiący miał na myśli (what is meant). To, co implikowane konwersacyjnie, zgodnie z teorią Grice’a jest tym, co mówiący miał na myśli, a nie tym, co wypowiedział. Rozmówca, aby ustalić, co zostało powiedziane, musi jedynie posłużyć się regułami znaczeniowymi języka, w którym tę wypowiedź sformułowano, oraz przyjąć założenie, że jest ona dosłowna i ma charakter komunikacyjny [Witek, 2010, s. 182]. Interpretacja tego, co mówiący miał na myśli, jest natomiast procesem bardziej złożonym: jest ono ustalane w drodze wnioskowań, w których uwzględnia się kontekst poznawczy złożonych wypowiedzi [Witek, 2010, s. 182]. Innymi słowy: to, co implikowane konwersacyjnie, zostaje odczytane za pomocą wnioskowań, którymi kieruje założenie o przestrzeganiu zasady współpracy wyrażonej w postaci maksym konwersacyjnych. Teoria ta jest więc teorią intencjonalno-inferencyjną. W późniejszych latach Dan Sperber oraz Deirdre Wilson [1995] rozwinęli alternatywną dla teorii Grice’a teorię relewancji, zastępującą maksymy konwersacyjne zasadą relewancji. Obecnie rozwijane są podejścia neo-Griceowskie, które odchodzą od lokalizowania tego, co implikowane konwersacyjnie na poziomie znaczenia wtórnego, zamiast tego umieszczając treści implikowane na poziomie znaczenia pierwotnego [Jaszczolt, 2012]. Wymieńmy teraz najważniejsze własności implikatur konwersacyjnych [Levinson, 2010, s. 133-134]: 
1. Odwoływalność: implikatura może zostać odwołana, jeżeli do przesłanek wejściowych dodamy nowe przesłanki.

2. Nieodrywalność: implikatury nie są przywiązane do językowej formy wypowiedzi, a raczej do tego, co zostało powiedziane. Innymi słowy, użycie synonimów słów znajdujących się w wypowiedzi nie odwołuje implikatury.

3. Obliczalność: dla każdej implikatury można skonstruować argument, który pokazuje, jak przy użyciu maksym konwersacyjnych i założonej współpracy można przejść od znaczenia dosłownego do implikatury.

4. Niebycie konwencjonalnym: implikatury nie są częścią konwencjonalnego znaczenia wyrażeń językowych.

Implikatury konwersacyjne wydają się jednak mieć również inne własności, a jedną z nich jest możliwość ich wzmacniania, na którą zwrócił uwagę Jerry Sadock (1978). Własność ta stanowi punkt centralny niniejszej pracy i zostanie omówiona w dalszej części artykułu.

\section{Presupozycje}

Wyraźne zdefiniowanie klasy zjawisk, które są określane mianem presupozycji, nastręcza więcej trudności niż w przypadku implikatur konwersacyjnych. Podkreślmy najpierw, że używając w niniejszym artykule terminu „presupozycja”, odnosimy się tu do presupozycji w rozumieniu technicznym, a nie potocznym. Jak pisze Stephen Levinson [2010, s. 195], potoczne rozumienie terminu "presupozycja” obejmuje pewne przyjęte $\mathrm{w}$ tle założenia, $\mathrm{w}$ świetle których dana wypowiedź nabiera sensu, natomiast $\mathrm{w}$ rozumieniu technicznym wyznacza ono pewną klasę wnioskowań pragmatycznych, które można wyodrębnić za pomocą specyficznych testów językowych (np. niezmienniczość wobec negacji). Presupozycjami w technicznym sensie jako pierwszy zajmował się Gottlob Frege.

Weźmy zdanie:

[2] Kepler umarł w nędzy.

Wypowiadając owo zdanie, twierdzi Frege, zakładamy, że nazwisko „Kepler” kogoś lub coś desygnuje oraz że „»Kepler« kogoś lub coś desygnuje” nie jest elementem znaczenia zdania [1] [Frege, 1967, s. 240]. Należy również zaobserwować, że negacja zdania „Kepler umarł w nędzy” wydaje się nieść to samo założenie [Van der Sandt, 1988]. Tak więc zarówno zdanie [1], jak i zdanie:

[3] Kepler nie umarł w nędzy.

zakładają:

[4] „Kepler” kogoś lub coś desygnuje. 
Takie relacje pomiędzy zdaniami Strawson nazywał presupozycją, twierdząc, że jest ona specjalnym rodzajem wnioskowania pragmatycznego, różnym od wynikania logicznego i biorącym się z konwencji związanych z użyciem wyrażeń [Levinson, 2010, s. 199]. W przykładach podanych powyżej mieliśmy okazję zaobserwować jedną z najbardziej znanych własności presupozycji: presupozycje zdania zostają zachowane, nawet jeżeli zdanie zostanie zanegowane. Próby opisania zjawiska presupozycji były podejmowane zarówno na gruncie semantyki, jak i pragmatyki. W ujęciu semantycznym presupozycje traktowane są jako własności zdań. Należy jednak zauważyć, że na gruncie semantycznych teorii presupozycji trudno jest wyjaśnić pewne ich własności, takie jak rzutowanie. Problem rzutowania dotyczy tego, które z presupozycji zdań składowych zostają zachowane w zdaniach złożonych. Terence Langendoen i Harris Savin [1971] utrzymywali, że presupozycje zdań złożonych są prostą sumą presupozycji zdań składowych. Rozwiązanie to nie pozwala nam jednak trafnie przewidywać tego, w jaki sposób zachowują się presupozycje w zdaniach złożonych, ze względu na to, że po pierwsze: presupozycje zostają zachowane w pewnych kontekstach, w których znikają konsekwencje logiczne, a po drugie: presupozycje znikają w kontekstach, w których oczekujemy, że zostaną zachowane, tak jak konsekwencje logiczne (Levinson, 2010, s. 223). Teorie pragmatyczne natomiast starają się opisywać presupozycje w kategoriach czynników kontekstowych, przekonań lub wiedzy nadawcy i odbiorcy [Van der Sandt, 1988]. W związku z tym w ujęciu pragmatycznym nie mówi się o presupozycjach zdań, lecz o presupozycjach mówiącego, choć Robert Stalnaker [1973] twierdził, że możemy mówić o zdaniach jako posiadających presupozycje w znaczeniu wtórnym. Na początku lat 90. zaczęły pojawiać się koncepcje presupozycji, które odchodziły od standardowego podziału semantyka/pragmatyka. Nurt ten zapoczątkował Rob Van Der Sandt w artykule Presuppositon projection as anaphora resolution [1992]. W koncepcjach tych presupozycje są traktowane jako anafory. Podejście to zostało wykorzystane między innymi na gruncie Discourse Representation Theory (DRT), Segmented Discourse Representation Theory (SDRT) oraz Default Semantics [Jaszczolt, 2012].

Istnieje liczna klasa elementów leksykalnych oraz konstrukcji zdaniowych, które niosą ze sobą presupozycje. Van der Sandt [1988] wymienia dwanaście różnych konstrukcji wprowadzających presupozycje, Levinson [2010] - trzynaście. Poniżej opiszemy te konstrukcje wprowadzające presupozycje, które zostały wykorzystane w badaniu.

Czasownikami faktywnymi nazywamy takie czasowniki, które wprowadzają presupozycję, że sąd następujący po nich jest sądem prawdziwym [Karttunen, 1971]. Są to czasowniki takie jak „wiedzieć”, „uświadomić sobie”, „żałować” [Karttunen, 1971; Levinson, 2010]. Przykładowo:

[5] Jan nie żałował, że wyruszył w podróż na Marsa (presuponuje: Jan wyruszył w podróż na Marsa).

Czasowniki zmiany stanu to czasowniki: „przestać”, „zaczać”, „kontynuować, „skończyć”, „przerwać”, „zabrać”, „wejść”, „przyjść”, „íćc”, „przyjechać”. Przykładowo: 
[6] Jan przerwał przygotowania do lotu na Marsa (presuponuje: Jan przygotowywał się do lotu na Marsa).

Określenie czasowe to sformułowania takie jak „zanim”, „gdy”, „od kiedy”, „po”, „w czasie”, „zawsze gdy”. Przykładem zdania z określeniem czasowym jest:

[7] Od kiedy Jan dostał się do programu lotów na Marsa, musi bardzo ciężko pracować (presuponuje: Jan dostał się do programu lotów na Marsa).

Czasowniki implikacyjne stanowią jedną z ciekawszych konstrukcji wprowadzających presupozycje. Można powiedzieć, że czasowniki implikacyjne implikują pewne sądy, nie jest to jednak implikacja w sensie logicznym, a raczej w jej słabszym sensie, w jakim używał jej Austin [1962]. Sądy te są pewnego rodzaju koniecznymi warunkami dla czynności opisywanych przez czasowniki implikacyjne. Odmienne czasowniki implikacyjne niosą ze sobą różne presupozycje:

[8] „X zapomniał/nie zapomniał p” presuponuje: „X powinien był p” lub „X zamierzał p”.

[9] „X zdołał/nie zdołał p” presuponuje: „X próbował p”.

[10] „X przydarzyło się p” presuponuje: „X nie planował p”.

[11] „X uniknął p” presuponuje: „od X oczekiwało się, że p” lub „X powinien był p”, lub „X zazwyczaj p”.

Jak już wcześniej wspomniano, niezmienniczość wobec negacji jest najbardziej charakterystyczną cechą presupozycji. Ponadto presupozycje w pewnych kontekstach mogą zostać odwołane [Levinson, 2010]. Są one również nieodrywalne, czyli wywoływane przez konkretne jednostki leksykalne lub konstrukcje zdaniowe. Przejdźmy teraz do opisu zjawiska wzmacnialności.

\section{Wzmacnialność}

Omówiliśmy już pokrótce zjawiska implikatur konwersacyjnych oraz presupozycji, wymieniliśmy też ich główne własności. Powróćmy teraz do jednej z mniej znanych własności implikatur konwersacyjnych: wzmacnialności, o której wcześniej wspominaliśmy. Stephen Levinson, powołując się na Jerry’ego Sadocka, stwierdza: „implikatury wydają się być jedynego rodzaju pragmatycznymi lub semantycznymi wnioskowaniami, które cechują się nieskrępowaną wzmacnialnością, tzn. mogą być połączone $\mathrm{z}$ jawnym stwierdzeniem tego, co jest ich treścią, nie wywołując poczucia nieprawidłowej redundancji (anomalous redundancy)" [Levinson, 2010, s. 137-138]. Konsekwencją tej hipotezy jest stwierdzenie, że presupozycje nie mogą podlegać wzmocnieniom bez wywoływania poczucia nieprawidłowej redundancji, chyba że uznamy presupozycje za pewien rodzaj implikatur konwersacyjnych. Przyjrzyjmy się teraz przykładom, które obrazują wzmocnienie implikatur konwersacyjnych: 
[12] A: Czy idziemy dzisiaj do kina?

B: Niestety bardzo boli mnie głowa, nie idziemy dzisiaj do kina.

Widzimy, że osoba B jawnie zawarła w swojej wypowiedzi to, co w przykładzie [1] było implikowane konwersacyjnie, czyli informację o tym, że nie chce iść do kina. Implikatura konwersacyjna została więc w tym wypadku wzmocniona. Zgodnie $\mathrm{z}$ hipotezą Sadocka wzmocnienie implikatury zdaje się nie wywoływać w tym wypadku poczucia nieprawidłowej redundancji. Dlaczego tak się dzieje? Definicje prawidłowej i nieprawidłowej redundancji, jakie zostały użyte podczas badania, zostaną opisane w dalszej części tekstu; tutaj odwołamy się jedynie do intuicyjnego rozumienia tych terminów: w przypadku wymiany zdań w przykładzie [2] brak anomalności zdaje się wynikać z tego, że otwarte wypowiedzenie tego, co implikowane konwersacyjnie, nie sprawia wrażenia zwykłego powtórzenia informacji, która już wcześniej (przed wzmocnieniem) była zawarta w wypowiedzi. Możemy bez większego problemu wyobrazić sobie konteksty komunikacyjne, w których otwarte zawarcie tego, co implikowane konwersacyjnie, sprawi, że wypowiedź będzie bardziej zrozumiała. W przypadku wzmocnienia implikatury konwersacyjnej mamy więc do czynienia z sytuacją, w której wzmocniona wypowiedź zdaje się nieść więcej informacji niż niewzmocniona i informacje te mogą przyczynić się do lepszego zrozumienia owej wypowiedzi. Co natomiast stanie się, gdy wzmocnieniu poddamy presupozycje? Spójrzmy na przykłady:

[13] Alan Shepard nie żałował, że wylądował na Księżycu i wylądował na Księżycu.

[14] Beata przestała popełniać błędy w pracy i popełniała błędy w pracy.

[15] Jan nie zdołał zahamować przed skrzyżowaniem i próbował zahamować przed skrzyżowaniem.

W powyższych przykładach jawnie zawarto w wypowiedziach treści, które były w nich presuponowane. Wypowiedzi te wydają się mieć charakter anomalny w szczególności zdania w przykładach [12] i [13]. Anomalność ta wynika z faktu, że treść dodana poprzez wzmocnienie sprawia wrażenie zbędnego powtórzenia tego, co już wcześniej zostało powiedziane. Dodana treść w żaden sposób nie przyczynia się do lepszego zrozumienia wypowiedzi. Zdanie w przykładzie [14] ma nieco inny charakter. Wprawdzie również mamy tu do czynienia z powtórzeniem, jednak możemy sobie wyobrazić taki kontekst komunikacyjny, w którym informacja o tym, że Jan próbował zahamować przed skrzyżowaniem, może przyczynić się do lepszego zrozumienia wypowiedzi. Zauważmy, że w każdym z trzech przykładów presupozycje wywoływane są przez odmienne konstrukcje wprowadzające presupozycje. W przypadku zdania [12] mamy do czynienia z czasownikiem faktywnym „żałować”, w zdaniu [13] występuje czasownik zmiany stanu „przestać”, a w zdaniu [14] pojawia się czasownik implikacyjny „zdołać”. Te wstępne obserwacje stanowiły punkt wyjścia do częściowego zakwestionowania hipotezy Sadocka. Wydaje się bowiem, że przynajmniej w niektórych sytuacjach i dla niektórych konstrukcji wprowadzających presupozycje istnieje możliwość ich wzmocnienia bez wywoływania poczucia nieprawidłowej redundancji lub że owo poczucie będzie wyraźnie mniejsze niż w przypadku 
innych konstrukcji. Jest też prawdopodobne, że sposób, w jaki konstruujemy zdanie zawierające wzmocnienie, ma wpływ na poczucie nieprawidłowej redundancji. I tak na przykład użycie spójnika „ale” zamiast „i” w zdaniach [13]-[15] mogłoby sprawić, że redundancja będzie mniej odczuwalna ${ }^{1}$. W eksperymencie zdecydowano się na użycie spójnika „i”, jednak wpływ różnych spójników na poczucie nieprawidłowej redundancji może stanowić punkt wyjścia do dalszych badań.

\section{Redundancja oraz nieprawidłowa redundancja}

„Redundancja” jest terminem wykorzystywanym w wielu dziedzinach nauki. Należy jednak podkreślić, że w niniejszej pracy, mówiąc „redundancja”, mamy na myśli redundancję językową. Termin ten jest definiowany na różne sposoby. Na przykład Sharon Hunnicutt $[1985$, s. 53] stwierdza: „Redundancja to (...) informacja w kompletnym zdaniu wykraczająca poza to, co konieczne" (tłum. własne); owa informacja pozwala na podtrzymanie procesu komunikacji w przypadku zakłóceń. Peter Nübold oraz John Turner [1983, s. 33] podają z kolei funkcjonalną definicję redundancji, określając ją jako „Własność źródła informacji, która sprawia, że odbiorca komunikatu jest w stanie zrekonstruować treść przekazywanej informacji w sytuacji, gdy jej transmisja została zakłócona (...) i zinterpretować ją we właściwy sposób” (tłum. własne). Ernst-Jan C. Wit i Marie Gillette [1999, s. 12] starają się zdefiniować zjawisko redundancji językowej, podając następujące funkcje, jakie pełni ona w procesie komunikacji:

1. Zwiększenie zrozumiałości.

2. Rozstrzyganie dwuznaczności.

3. Izolowanie pewnej cechy.

4. Kontrastowanie elementów.

5. Podkreślanie lub intensyfikacja.

6. Tworzenie efektu „poetyckiego".

Widzimy więc, że zwiększanie zrozumiałości wypowiedzi w procesie komunikacji wydaje się podstawową i najważniejszą funkcją redundancji językowej [Wit, Gillette, 1999, s. 12]. Proces komunikacji językowej może zostać zakłócony poprzez liczne czynniki występujące zarówno po stronie odbiorcy, jak i nadawcy. Źródłem zakłóceń może być również sam kanał komunikacyjny. Istotne jest zatem, aby komunikować informacje w sposób, który zwiększa prawdopodobieństwo sukcesu komunikacyjnego pomimo owych czynników zakłócających. Nie jest więc niczym dziwnym, że proces komunikacji zawiera elementy redundantne. Niektórzy argumentują wręcz, że redundancja językowa jest elementem niezbędnym do przekazywania złożonych treści [Campbell, 1982]. Uwzględniając powyższe uwagi, możemy przyjąć, że mówiąc o prawidłowej redundancji językowej, mamy na myśli takie zjawisko, w wyniku którego informacje, jakie staramy się przekazać odbiorcy, są łatwiejsze do odczytania. Zwróćmy jeszcze uwagę na pewien inny aspekt redundancji językowej; otóż można wyróżnić [Wit, Gillette, 1999] dwa jej rodzaje: redundancję gramatyczną oraz redundancję kontekstową. Mówiąc o redundancji gramatycznej, mamy na myśli sterowane

\footnotetext{
Dziękuję jednemu z recenzentów za zwrócenie uwagi na tę kwestię.
} 
wewnętrznymi regułami funkcjonowanie systemu językowego, w którym dwa lub więcej elementów pełni tę samą funkcję [Wit, Gillette, 1999, s. 4]. Przykładem tego rodzaju redundancji jest używanie morfemu $-s$ do oznaczania czasowników w trzeciej osobie liczby pojedynczej czasu teraźniejszego w języku angielskim. Jako że język angielski nie dopuszcza pomijania zaimków osobowych, morfem ten jest zbędny. Redundancja gramatyczna jest obligatoryjna, to znaczy żaden z elementów redundantnych nie może zostać pominięty [Wit, Gillette, 1999, s. 4]. Redundancja kontekstowa oznacza powtarzanie informacji, które nie jest konieczne z punktu widzenia gramatyki, przy czym owe powtórzenie może być reprodukcją identycznych elementów informacji lub też takich, które są tylko pozornie identyczne [Wit, Gillette, 1999]. Wit i Gillette [1999, s. 10] proponują następujący podział redundancji kontekstowej:

1. Powtórzenia identyczne lub synonimiczne.

2. Powtórzenia izolujące.

3. Powtórzenia kontrastujące.

4. Powtórzenia różnicujące.

Wydaje się, że przypadki wzmacniania presupozycji należałoby zaklasyfikować jako powtórzenia identyczne lub synonimiczne. $Z$ takim rodzajem powtórzenia mamy do czynienia w zdaniu [16]:

[16] Na dworze padało i padało.

W zdaniach tego typu zawarte są dwa lub więcej identyczne bądź synonimiczne elementy [Wit, Gillette, 1999, s. 10]. Należy dodać, że Levinson [2010] sugeruje, iż zdania takie jak te mogą funkcjonować jak swego rodzaju implikatury konwersacyjne. Natomiast przypadki wzmacniania implikatur konwersacyjnych zdają się odpowiadać najbardziej kategorii powtórzeń różnicujących, które są najbardziej kontekstowo zależne ze wszystkich rodzajów redundancji kontekstowej. Jest to ujednoznacznienie słowa w niedwuznacznym kontekście poprzez dodanie do niego elementu, który nie byłby powtórzeniem w dwuznacznym kontekście [Wit, Gillette, 1999, s. 11]. Wyobraźmy sobie, że rozmawia ze sobą dwóch astronomów. Jeden mówi do drugiego:

[17] Czy słyszałeś o nowym odkryciu na temat Europy?

Dla uczestników tej konwersacji kontekst jest niedwuznaczny. Obaj rozumieją, że chodzi o Europę, która jest księżycem Jowisza. Dlatego zdanie:

[18] Czy słyszałeś o nowym odkryciu na temat Europy, która jest księżycem Jowisza?

zawiera treść, która wydaje się zbędna. Jednocześnie, przy zmianie kontekstu na taki, w którym konwersacja odbywa się pomiędzy astronomem a jego znajomym, który nie posiada szczegółowej wiedzy na temat księżyców orbitujących wokół planet Układu Słonecznego, zdanie [18] nie zawiera zbędnych informacji.

Posługując się powyższymi informacjami, na potrzeby badania przyjęto następujące definicje redundancji językowej oraz nieprawidłowej redundancji językowej: 
1. Redundancją językową nazwiemy takie powtórzenie informacji, które służy zwiększeniu zrozumiałości wypowiedzi.

2. Nieprawidłową redundancją językową nazwiemy takie powtórzenie informacji, które zmniejsza stopień zrozumiałości wypowiedzi.

Definicje te zawierają dwie najważniejsze cechy redundancji: to, że sprowadza się ona do powtórzenia informacji, oraz jej główną funkcję, czyli zwiększenie zrozumiałości wypowiedzi w przypadku prawidłowej redundancji. W przypadku nieprawidłowej redundancji cechą definicyjną jest przeciwieństwo funkcji prawidłowej redundancji, a zatem zmniejszenie zrozumiałości wypowiedzi. Należy podkreślić, że w obu przypadkach mamy tu na myśli redundancję kontekstową, gdyż co do presupozycji i implikatur konwersacyjnych wzmocnienie obejmuje redundantne dodanie informacji do treści wypowiedzi wynikające z czynników innych niż gramatyczne. Kolejnym ważnym spostrzeżeniem jest to, jakiego rodzaju treści zostają dodane do wypowiedzi w przypadku wzmocnienia odpowiednio implikatur konwersacyjnych i presupozycji. Przy presupozycji jest to najczęściej dodanie treści, która była już wcześniej kodowana leksykalnie (wyjątek stanowią tu jedynie czasowniki implikacyjne). Jeśli chodzi o implikatury konwersacyjne, treść, która została dodana do wypowiedzi po jej wzmocnieniu, jest redundantna w tym sensie, że już wcześniej była zawarta w tym, co nadawca miał na myśli (w sensie Gricéa), wypowiadając dane zdanie.

\section{Problemy i metoda badań własnych}

Główny problem badawczy przeprowadzonego badania brzmiał następująco: czy wzmocnienie presupozycji, w odróżnieniu od wzmocnienia implikatur konwersacyjnych, wywołuje efekt niewłaściwej redundancji? Dodatkowo w toku badania starano się odpowiedzieć na pytanie, czy odmienne rodzaje konstrukcji wprowadzających presupozycje różnią się pod względem wywoływania poczucia nieprawidłowej redundancji. Zmienną zależną w badaniu była redundancja językowa wzmocnionej treści, której definicję przedstawiono wyżej. Zmienną niezależną był rodzaj konstrukcji językowej. Zmienna ta przyjmowała pięć poziomów, w zależności od konstrukcji językowej. Przypomnijmy, że w badaniu wykorzystano następujące konstrukcje językowe: implikatury konwersacyjne, czasowniki faktywne, czasowniki zmiany stanu, określenia czasowe oraz czasowniki implikacyjne. Sformułowane zostały następujące hipotezy badawcze:

1. W przypadku wzmocnienia implikatury konwersacyjne wywołują poczucie nieprawidłowej redundancji w mniejszym stopniu niż presupozycje.

2. W przypadku wzmocnienia różne rodzaje konstrukcji wprowadzających presupozycje wywołują poczucie nieprawidłowej redundancji w różnym stopniu.

Hipotezy zerowe dla powyższych hipotez badawczych brzmiały następująco:

1. W przypadku wzmocnienia nie zachodzi różnica $\mathrm{w}$ wywoływaniu poczucia nieprawidłowej redundancji między implikaturami konwersacyjnymi a presupozycjami. 
2. W przypadku wzmocnienia nie zachodzi różnica $\mathrm{w}$ wywoływaniu poczucia niewłaściwej redundancji między różnymi rodzajami konstrukcji wprowadzających presupozycje.

Operacjonalizacja zmiennych oraz procedura badania zostały zainspirowane eksperymentem przeprowadzonym przez Joannę Rączaszek-Leonardi i Nicolettę Caramelli [Rączaszek-Leonardi, 2011]. Badanie te miało dwa wymiary. Po pierwsze, starano się wykazać, że istnieje związek między rodzajem gramatycznym słowa, definiowanym jako syntaktycznie niezależna, formalna własność rzeczowników, wyznaczana przez różnice w łączliwości syntaktycznej, a jego semantycznymi poziomami przetwarzania [Rączaszek-Leonardi, 2011]. Dokładniej badanie dotyczyło tego, w jakim stopniu rodzaj gramatyczny rzeczownika desygnującego dany przedmiot ma wpływ na ocenianie go jako posiadającego cechy bardziej męskie lub żeńskie. Po drugie, badano, jaki wpływ na ten związek ma wykorzystany język, czyli czy ocena męskości vs. żeńskości jest zgodna z rodzajem gramatycznym rzeczownika w danym języku (badanie zostało przeprowadzone w językach włoskim i polskim). Dokładny opis badania brzmi następująco:

W badaniu porównywano wpływ rodzaju gramatycznego na opisywanie przedmiotów z różnych kategorii semantycznych w dwóch językach: polskim i włoskim. (...) Przedmioty dobrano $\mathrm{w}$ ten sposób, by ich nazwy reprezentowały określone kombinacje włoskiego i polskiego rodzaju gramatycznego. Zastosowano metodę (...) polegającą na opisie przedmiotów za pomocą przymiotników oraz ocenie, w jakim stopniu te ostanie niosą konotację „męski” versus „żeński”. Zadania opisu przedmiotów i oceny przymiotników dokonywane były przez różne grupy osób badanych, co miało uniemożliwić świadome stosowanie rodzaju gramatycznego jako wskazówki dla podawanych opisów. Badanie miało zatem dwie fazy: w pierwszej uczestnicy opisywali za pomocą przymiotników przedmioty przedstawiane jako słowa lub zaprezentowane na zdjęciach. W wyniku tej fazy powstał zbiór przymiotników, które w fazie drugiej inna grupa uczestników, pochodząca z podobnej populacji, oceniała na wymiarach „męski” i „żeński”. Rezultatem drugiej fazy było uzyskanie dla każdego przymiotnika wartości tzw. nasycenia rodzajem czy ładunku rodzaju, stanowiącego różnicę między oceną na skali „męski” i „żeński”. Następnie miarę uzyskaną w fazie drugiej dla każdego przymiotnika zastosowano do opisów otrzymanych w fazie pierwszej i wykonano analizy statystyczne ładunku rodzaju w poszczególnych podgrupach rzeczowników wyznaczonych ze względu na wartości cechy rodzaju gramatycznego w dwóch językach [Rączaszek-Leonardi, 2011, s. 76].

Osobami badanymi byli studenci Uniwersytetu Warszawskiego oraz Uniwersytetu Bolońskiego. Metodą statystyczną wykorzystaną do badania była wieloczynnikowa analiza wariancji.

Badając wzmacnialność presupozycji oraz implikatur konwersacyjnych, zastosowano podobny, lecz uproszczony schemat badania. Po pierwsze, ze względu na cel i konstrukcję eksperymentu nie istniała konieczność badania osób posługujących się różnymi językami. Po drugie, badanie nie dotyczyło relacji między cechami syntaktycznymi słów a ich semantycznym przetwarzaniem, tylko zbędności informacji 
zawartych w wypowiedzi. Nie była więc konieczna dwustopniowa struktura badania, która pierwotnie miała uniemożliwić sugerowanie się rodzajem gramatycznym przedmiotu podczas jego oceny. Po trzecie, zastosowano jedynie jedną skalę do oceny wypowiedzi. Po czwarte, do analizy danych zastosowano jednoczynnikową analizę wariancji z powtarzanym pomiarem.

Materiałem testowym wykorzystanym w badaniu był zbiór wypowiedzi językowych zawierających interesujące $\mathrm{z}$ punktu widzenia badania konstrukcje językowe. Zbiór zdań wykorzystanych $\mathrm{w}$ badaniu został skonstruowany specjalnie na potrzeby badania. Jako że implikatury konwersacyjne rozumiane są w kontekście, konieczne było stworzenie dialogów zawierających implikatury. Presupozycje nie są w tym stopniu zależne od kontekstu, jednak w celu ujednolicenia materiału testowego również zdecydowano się na umieszczenie ich w dialogach. Ogółem w badaniu znalazło się 50 przykładów różnych dialogów, po 10 na każdy rodzaj badanej konstrukcji językowej. Każda $\mathrm{z}$ wypowiedzi była przygotowana $\mathrm{w}$ dwóch wersjach: $\mathrm{w}$ pierwszej treści presuponowane oraz implikowane nie były wzmocnione, tzn. treść implikowana lub presuponowana nie była zawarta $\mathrm{w}$ wypowiedzi. W wersji drugiej treść presuponowana lub implikowana była zawarta w wypowiedzi, zawsze na jej końcu. Zadaniem osób badanych było ocenienie dodanej (wzmocnionej) treści na pięciostopniowej skali. Poszczególne oceny na skali zostały opisane w następujący sposób:

1. Dodatkowa treść, która pojawiła się w wypowiedzi, nie jest powtórzeniem wcześniej zawartych w niej informacji, a nawet ułatwia jej zrozumienie.

2. Dodatkowa treść, która pojawiła się w wypowiedzi, nie jest powtórzeniem, ale nie ułatwia też jej zrozumienia.

3. Dodatkowa treść jest neutralna pod kątem powtórzenia oraz ułatwienia zrozumienia wypowiedzi.

4. Dodatkowa treść, która pojawiła się w wypowiedzi, jest powtórzeniem informacji już w niej zawartych, ale takie połączenie nie utrudnia zrozumienia wypowiedzi.

5. Dodatkowa treść, która pojawiła się w wypowiedzi, jest całkowicie nieprawidłowym powtórzeniem informacji wcześniej już w niej zawartej i może utrudniać rozumienie wypowiedzi.

Podczas konstruowania opisu skali wzięto pod uwagę teoretyczne założenia funkcjonowania implikatur konwersacyjnych oraz presupozycji. Przyjęto, że implikatury konwersacyjne powinny być systematycznie oceniane na jednym krańcu skali, natomiast presupozycje na drugim. W związku z tym ocena "1" ujmuje własności implikatur: treść wzmocniona nie jest dosłownym powtórzeniem informacji zawartej już wcześniej, może również ujednoznaczniać wypowiedź, a więc zwiększać stopień jej zrozumienia. Na drugim końcu skali ocena „5” ujmuje własności konstrukcji językowych wywołujących poczucie nieprawidłowej redundancji przy wzmocnieniu (zgodnie z przyjętą definicją), to znaczy takich, które są powtórzeniem dosłownym zmniejszającym stopień zrozumienia wypowiedzi. Widać zatem, że skala zawiera w sobie dwa elementy: rodzaj powtórzenia (dosłowne vs. synonimiczne) oraz wpływ na rozumienie wypowiedzi (ułatwianie vs. utrudnianie). Konstrukcja taka jest uprawomocniona definicją redundancji językowej, która także zawiera te dwa elementy. Ponadto należy zwrócić uwagę, że dwa wymiary skali zmieniają się na kontinuum od 
prawidłowej redundancji językowej do nieprawidłowej redundancji, zachowana jest więc ciągłość skali. Wynik każdej wypowiedzi na skali traktowany jest jako wskaźnik poczucia redundancji wzmocnionej treści.

Badanie ze względu na swoją strukturę mogło zostać przeprowadzone w sposób grupowy. Badani byli podzieleni tak, że liczebność poszczególnych grup badawczych nie przekraczała 20 osób. Na początku badania grupie przekazano instrukcję w postaci prezentacji multimedialnej połączonej z instrukcją słowną prowadzącego badanie. W instrukcji zawarto przykładowe pozycje testowe, wyjaśnienie skali i sposobu oceniania poszczególnych pozycji testowych oraz zaprezentowano sposób i czas wyświetlania się kolejnych pozycji testowych. Badanie właściwe miało postać prezentacji multimedialnej. Każda z wypowiedzi wyświetlała się na okres 7 sekund, po czym również na okres 7 sekund wyświetlała się wersja wypowiedzi z dodaną treścią, wzmacniająca zawartą w wypowiedzi presupozycję bądź implikaturę konwersacyjną. Dodana treść była zaznaczona kolorem zielonym w celu zwiększenia czytelności i uniknięcia sytuacji, w której badany nie będzie pewny tego, jaka informacja została dodana do wypowiedzi. Następnie na okres 10 sekund wyświetlała się plansza ze wzmocnioną wersją wypowiedzi oraz napisem: „Oceń odpowiedź nr x”. Napis wyświetlany był kolorem czerwonym. W szóstej sekundzie napis „Oceń odpowiedź nr x” zaczynał migać w celu ostrzeżenia przed kończącym się czasem. Następnie na okres 3 sekund wyświetlana była pusta plansza. Całość badania trwała 22 minuty i 30 sekund. Badani oceniali każdą wypowiedź na jednostronicowym arkuszu, który zawierał też opis skali, za pomocą której oceniano wypowiedzi.

Osobami badanymi byli studenci Uniwersytetu Szczecińskiego oraz Zachodniopomorskiego Uniwersytetu Technologicznego. Zgłoszenie do badań było dobrowolne. Minusem niezastosowania doboru losowego jest utrudniona możliwość generalizacji wyników badań na populację ogólną. Jednocześnie zakładano, że studenci są osobami sprawnie posługującymi się językiem polskim, co było istotnym czynnikiem w badaniu. Ponadto wybór studentów jako osób badanych ujednolicał grupę badaną pod kątem pewnych zmiennych (np. wiek, wykształcenie), co zmniejszało wpływ owych zmiennych na wariancję wyników.

Przed badaniem właściwym przeprowadzono badanie pilotażowe na małej grupie osób $(\mathrm{N}=5)$. Celem badania pilotażowego było zebranie opinii na temat przebiegu badania oraz jasności instrukcji, istotnym przedmiotem konsultacji były czasy wyświetlania wypowiedzi. Uwagi zebrane podczas dyskusji po badaniu pilotażowym zostały wykorzystane do modyfikacji pewnych aspektów procedury przed badaniem właściwym. Badania właściwe zostały przeprowadzone na studentach Uniwersytetu Szczecińskiego oraz Zachodniopomorskiego Uniwersytetu Technologicznego $(\mathrm{N}=48)$.

\section{Analiza statystyczna oraz wyniki}

Jak już wcześniej wspomniano, do analizy statystycznej danych wykorzystano jednoczynnikową analizę wariancji z powtarzanym pomiarem. Schemat ten jest wykorzystywany, kiedy osoba badana uczestniczy we wszystkich warunkach badania (na wszystkich poziomach zmiennej niezależnej), porównujemy więc wyniki danej osoby 
do jej własnych wyników [Niewiarowski, 2013]. Najważniejszą korzyścią z wykorzystania schematu z powtórzonym pomiarem jest zmniejszenie wpływu różnic indywidualnych na uzyskiwane pomiary do minimum, jak również zwiększenie prawdopodobieństwa, że za wariancję wyników odpowiada manipulacja zmienną niezależną [Niewiarowski, 2013, s. 101-102]. Wadą schematu z powtarzanym pomiarem jest możliwość pojawienia się efektu wprawy oraz efektu zmęczenia [Niewiarowski, 2013]. Należy także dodać, że wykorzystanie analizy wariancji z powtarzanym pomiarem wymagało pewnych czynności wstępnych w przygotowaniu danych zebranych w badaniu do analizy statystycznej. Mianowicie wyniki poszczególnych osób na poszczególnych stopniach zmiennej niezależnej zostały uśrednione. Oznacza to, że dla każdej osoby badanej obliczano średnią ocen wystawianych poszczególnym konstrukcjom językowym. Wszystkie obliczenia statystyczne zostały wykonane w programie IBM SPSS Statistics w wersji 21.

Przed właściwą analizą wariancji sprawdzono za pomocą testu Shapiro-Wilka, czy wartości zmiennych dla każdego poziomu zmiennej niezależnej przyjmują rozkład normalny. Wyniki testu wskazywały, że jedynie czasowniki implikacyjne zbliżały się do rozkładu normalnego. Należy jednak pamiętać, że pomimo niespełnienia założenia o rozkładzie normalnym zmiennych analiza wariancji będzie dawała poprawne rozwiązania, gdyż grupa osób badanych była większa niż 30 [Niewiarowski, 2013, s. 106]. Przeprowadzono ponadto test sferyczności Mauchly’ego, którego wyniki były istotne $(\alpha=0.00)$. Założenie o sferyczności danych należało zatem odrzucić, ale podobnie jak w przypadku założenia o rozkładzie normalnym nie jest ono konieczne do przeprowadzenia analizy wariancji z powtórzonym pomiarem.

Średnie oceny oraz odchylenia standardowe zmiennej zależnej na różnych poziomach zmiennej niezależnej wyglądały następująco:

Tabela 1. Średnie ocen oraz odchylenie standardowe

\begin{tabular}{|l|c|c|c|}
\hline & Średnia & $\begin{array}{c}\text { Odchylenie } \\
\text { standardowe }\end{array}$ & $\mathrm{N}$ \\
\hline 1. Implikatury & 1.6417 & .51523 & 48 \\
\hline 2. Czasowniki faktywne & 4.4042 & .44719 & 48 \\
\hline 3. Określenia czasowe & 4.5250 & .46927 & 48 \\
\hline 4. Czasowniki zmiany stanu & 4.2417 & .64009 & 48 \\
\hline 5. Czasowniki implikacyjne & 3.3125 & .90027 & 48 \\
\hline
\end{tabular}

Źródło: opracowanie własne.

Jak widać w powyższej tabeli, implikatury konwersacyjne były oceniane średnio najniżej pod kątem wywoływania poczucia nieprawidłowej redundancji, czasowniki faktywne, określenia czasowe i czasowniki zmiany stanu oceniano zaś najwyżej. Przejdźmy teraz do wyników statystyki F, które znajdują się w tabeli 2. 
Tabela 2. Wyniki testu efektów wewnątrzobiektowych

\begin{tabular}{|c|c|c|c|c|c|c|c|}
\hline & Źródło & $\begin{array}{c}\text { Typ III } \\
\text { sumy } \\
\text { kwadratów }\end{array}$ & $\mathrm{df}$ & $\begin{array}{l}\text { Sredni } \\
\text { kwadrat }\end{array}$ & $\mathrm{F}$ & Istotność & $\begin{array}{c}\text { Cząstkowe } \\
\text { Eta } \\
\text { Kwadrat }\end{array}$ \\
\hline \multirow{2}{*}{ 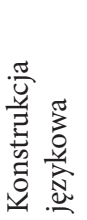 } & $\begin{array}{l}\text { Sferyczność } \\
\text { założona }\end{array}$ & 279.775 & 4 & 69.944 & 239.774 & .000 & .836 \\
\hline & $\begin{array}{l}\text { Greenhouse- } \\
\text {-Geisser }\end{array}$ & 279.775 & 2,845 & 98.024 & 239.774 & .000 & .836 \\
\hline
\end{tabular}

Źródło: opracowanie własne.

Analiza wariancji przeprowadzona w modelu wielozmiennowym ujawniła istotny efekt główny konstrukcji językowej $\mathrm{F}(4,43)=239,774 ; \mathrm{p}<0.01 ; \eta^{2}=0,84$. W celu sprawdzenia, na czym polega istota tego efektu, przeprowadzona została analiza post hoc (z korektą dla porównań wielokrotnych Bonferoniego) poprzez porównanie poziomu poczucia redundancji językowej we wszystkich warunkach eksperymentalnych między sobą, której wyniki znajdują się w tabeli 3.

Tabela 3. Wyniki analizy post hoc

\begin{tabular}{|c|c|c|c|c|c|c|}
\hline \multirow{2}{*}{$\begin{array}{l}\text { Konstrukcja } \\
\text { językowa (I) }\end{array}$} & \multirow{2}{*}{$\begin{array}{l}\text { Konstrukcja } \\
\text { językowa (J) }\end{array}$} & \multirow{2}{*}{$\begin{array}{c}\text { Różnica } \\
\text { średnich } \\
\quad(\mathrm{I}-\mathrm{J})\end{array}$} & \multirow{2}{*}{$\begin{array}{c}\text { Błąd } \\
\text { standardowy }\end{array}$} & \multirow{2}{*}{ Istotność } & \multicolumn{2}{|c|}{$\begin{array}{l}\text { 95\% przedział ufności } \\
\text { dla różnicy }\end{array}$} \\
\hline & & & & & $\begin{array}{c}\text { Dolna } \\
\text { granica }\end{array}$ & $\begin{array}{l}\text { Górna } \\
\text { granica }\end{array}$ \\
\hline \multirow{4}{*}{$\begin{array}{l}\text { Implikatura } \\
\text { (1) }\end{array}$} & 2 & $-2.763^{*}$ & .102 & .000 & -3.064 & -2.461 \\
\hline & 3 & $-2.883^{*}$ & .111 & .000 & -3.212 & -2.555 \\
\hline & 4 & $-2.600^{*}$ & .112 & .000 & -2.929 & -2.271 \\
\hline & 5 & $-1.671^{*}$ & .149 & .000 & -2.111 & -1.231 \\
\hline \multirow{4}{*}{$\begin{array}{l}\text { Czasowniki } \\
\text { faktywne (2) }\end{array}$} & 1 & $2.763^{*}$ & .102 & .000 & 2.461 & 3.064 \\
\hline & 3 & -.121 & .059 & .465 & -.295 & .053 \\
\hline & 4 & .163 & .093 & .855 & -.110 & .435 \\
\hline & 5 & $1.092^{*}$ & .132 & .000 & .702 & 1.482 \\
\hline \multirow{4}{*}{$\begin{array}{l}\text { Określenia } \\
\text { czasowe (3) }\end{array}$} & 1 & $2.883^{*}$ & .111 & .000 & 2.555 & 3.212 \\
\hline & 2 & .121 & .059 & .465 & -.053 & .295 \\
\hline & 4 & $.283^{*}$ & .086 & .018 & .031 & .536 \\
\hline & 5 & $1.213^{*}$ & .120 & .000 & .858 & 1.567 \\
\hline
\end{tabular}




\begin{tabular}{|l|c|c|c|c|c|c|}
\hline & 1 & $2.600^{*}$ & .112 & .000 & 2.271 & 2.929 \\
\cline { 2 - 7 } & 2 & -.163 & .093 & .855 & -.435 & .110 \\
\cline { 2 - 7 } \begin{tabular}{l} 
Czasowniki $\begin{array}{l}\text { zmiany stanu } \\
(4)\end{array}$ \\
\cline { 2 - 7 }
\end{tabular} & 3 & $-.283^{*}$ & .086 & .018 & -.536 & -.031 \\
\hline \multirow{3}{*}{$\begin{array}{l}\text { Czasowniki } \\
\text { implikacyjne }\end{array}$} & 5 & $.929^{*}$ & .112 & .000 & .601 & 1.258 \\
\cline { 2 - 7 }$(5)$ & 3 & $1.671^{*}$ & .149 & .000 & 1.231 & 2.111 \\
\cline { 2 - 7 } & 4 & $-1.092^{*}$ & .132 & .000 & -1.482 & -.702 \\
\hline
\end{tabular}

Źródło: opracowanie własne.

Poziom poczucia redundancji językowej dla implikatur konwersacyjnych był istotnie różny od poziomu poczucia redundancji językowej dla każdego z rodzajów konstrukcji wprowadzających presupozycje. Hipoteza zerowa dla pierwszej hipotezy badawczej zostaje więc odrzucona. Dodatkowo zaobserwowano istotne statystycznie różnice w poziomie poczucia redundancji językowej pomiędzy różnymi konstrukcjami wprowadzającymi presupozycje. Hipoteza zerowa dla drugiej hipotezy badawczej zostaje więc odrzucona.

\section{Dyskusja wyników}

Wyniki badania zdają się częściowo potwierdzać hipotezę Jerry’ego Sadocka o implikaturach konwersacyjnych jako jedynych wnioskowaniach pragmatycznych lub semantycznych, które mogą podlegać wzmocnieniom. $Z$ danych przedstawionych wyżej wynika, że implikatury konwersacyjne były systematycznie oceniane nisko na skali redundancji językowej, zaś różnice w wynikach między implikaturami konwersacyjnymi a innymi konstrukcjami językowymi były istotne statystycznie. Analizując wyniki implikatur konwersacyjnych w kontekście opisu skali, można wnioskować, że wzmocnienie implikatur nie tylko nie wywołuje poczucia zbędnej redundancji, ale może również pomagać w zrozumieniu wypowiedzi. Wniosek ten nie jest zaskakujący, jeżeli weźmiemy pod uwagę fakt, że zgodnie z teorią Grice’a to, co implikowane konwersacyjnie, jest tym, co mówiący ma na myśli, a więc musi zostać wywnioskowane przez odbiorcę. Ciekawiej układają się wyniki różnych konstrukcji wprowadzających presupozycje. Czasowniki implikacyjne $(\mathrm{M}=3,31, \mathrm{SD}=0,9)$ uzyskiwały oceny najbardziej neutralne. Odwołując się do opisu skali, można wnioskować, że wzmocnienie tych konstrukcji językowych nie wywołuje poczucia nieprawidłowej redundancji. Jednocześnie wzmocnienie czasowników implikacyjnych nie jest traktowane jako zabieg zwiększający zrozumiałość wypowiedzi. Najwyżej ocenianą na skali pozycją są określenia czasowe $(M=4,52, S D=0,47)$, następnie czasowniki faktywne $(M=4,4$, 
$\mathrm{SD}=0,45)$ i czasowniki zmiany stanu $(\mathrm{M}=4,24, \mathrm{SD}=0,64)$. Należy także dodać, że różnice w wynikach określeń czasowych i czasowników faktywnych nie są istotne statystycznie, podobnie jak między czasownikami zmiany stanu i czasownikami faktywnymi. Istotna statystycznie jest jednak różnica między czasownikami zmiany stanu oraz określeniami czasowymi.

Nie jest jasne, dlaczego czasowniki implikacyjne w odróżnieniu od innych konstrukcji wprowadzających presupozycje mogą podlegać wzmocnieniu. Jednym z możliwych wyjaśnień jest uznanie ich za pewnego rodzaju implikatury konwersacyjne. Wymagałoby to jednak przyjęcia, że są one odczytywane za pomocą tych samych mechanizmów co implikatury konwersacyjne, to zaś nie tłumaczy, dlaczego zostają zachowane podczas negacji oraz czemu w przeciwieństwie do implikatur nie były oceniane jako ułatwiające zrozumienie wypowiedzi. Należy zauważyć, że obecnie wykorzystywane teorie presupozycji nie uwzględniają odmienności czasowników implikacyjnych w kontekście wzmocnień. Owocnym kierunkiem badań nad problemem wzmacnialności presupozycji może być zjawisko akomodacji. Wymaga to założenia, że nieprawidłowa redundancja pojawiająca się w efekcie wzmocnienia zdań zawierających konstrukcje wprowadzające presupozycje jest wywołana wcześniejszą akomodacją presupozycji owych konstrukcji. W tej sytuacji brak poczucia nieprawidłowej redundancji w przypadku czasowników implikacyjnych może być tłumaczony tym, że ich presupozycje nie są akomodowane. Hipoteza ta stanowi podstawę kolejnych badań planowanych przez autora niniejszej pracy.

\section{BIBLIOGRAFIA}

Austin, J.L. (1962). How to Do Things with Words. Oxford: Clarendon Press.

Campbell, J. (1982). Grammatical Man, Information, Entropy, Language, and Life. New York: Simon \& Schuster.

Frege, G. (1967). Sens i nominat. Tłum. J. Pelc. W: J. Pelc (red.). Logika i język. Studia z semiotyki logicznej (s. 225-251). Warszawa: Wydawnictwo Naukowe PWN.

Grice, H.P. (1975). Logic and conversation. W: P. Cole, J.L. Morgan (red.). Syntax and Semantics. Volume 3: Speech Acts (s. 41-58). New York: Academic Press.

Hunnicutt, S. (1985). Intelligibility versus redundancy - conditions of dependency. Language and Speech, 28 (2), 47-56.

Jaszczolt, K.M. (2012). Default Semantics: Foundations of a Compositional Theory of Acts of Communication. Oxford: Oxford University Press.

Karttunen, L. (1971). Implicative verbs. Language, 47, 340-358.

Langendoen, D.T., Savin, H.B. (1971). The projection problem for presuppositions. W: C.J. Fillmore, D.T. Langendoen (red.). Studies in Linguistic Semantics (s. 55-62). New York: Holt, Rinehart \& Winston.

Levinson, S.C. (2010). Pragmatyka. Tłum. T. Ciecierski, K. Stachowicz. Warszawa: Wydawnictwo Naukowe PWN.

Niewiarowski, J. (2013). Wprowadzenie do analizy wariancji z powtarzanym pomiarem. W: S. Bedyńska, M. Cypryańska (red.). Statystyczny drogowskaz. Tom 2: Praktyczne wprowadzenie do analizy wariancji (s. 99-112). Warszawa: Wydawnictwo SWPS oraz Wydawnictwo Akademickie „Sedno”. 
Nübold, P., Turner, J. (1983). Linguistic redundancy in English aeronautical telephony: a case study. Technische Universität Carolo-Wilhelmina zu Braunschweig, Seminar für Anglistik und Amerikanistik.

Rączaszek-Leonardi, J. (2011). Zjednoczeni w mowie. Względność językowa w ujęciu dynamicznym. Warszawa: Wydawnictwo Naukowe Scholar.

Van der Sandt, R. (1988). Context and Presupposition. London: Croom Helm.

Van der Sandt, R. (1992). Presupposition projection as anaphora resolution. Journal of Semantics, 9, 333-377.

Sadock, J. (1978). On Testing for Conversational Implicature. W: P. Cole (red.), Syntax and Semantics Volume 9: Pragmatics (s. 281-298). New York: Academic Press.

Sperber, D., Wilson, D. (1995). Relevance: Communication and Cognition. Oxford: Blackwell.

Stalnaker, R. (1973). Presuppositions. Journal of Philosophical Logic, 2, 447-457.

Wit, E.-J.C., Gillette, M. (1999). What is Linguistic Redundancy? Technical Report, The University of Chicago. Pozyskano z: http://www.math.rug.nl/ ernst/linguistics/redundancy3.pdf.

Witek, M. (2010). Spór o podstawy czynności mowy. Szczecin: Wydawnictwo Naukowe Uniwersytetu Szczecińskiego. 